\title{
Validity of ultrasound examination in the diagnosis of acute appendicitis compared with surgical results
}

\author{
Hazim K. AL-Allaf
}

Department of Radiology, College of Medicine, Mosul University

(Ann. Coll. Med. Mosul 2007; 33(1\&2):51-58)

Received: $15^{\text {th }}$ May 2007; Accepted: $27^{\text {th }}$ Nov 2007

\section{ABSTRACT:}

Objective: To assess the validity of ultrasound examination in the diagnosis of acute appendicitis.

Methods: This case series study included 750 patients. From January 2003 to March 2007, patients with suspected acute appendicitis were sent to the radiological section in the ALJamhory teaching hospital and my private clinic for sonography.

A distended appendix with a lumen more than $6 \mathrm{~mm}$, aperistaltic appendix with appendicolith in its lumen are all signs and criteria for the diagnosis of acute appendicitis.

Result: Of the 750 patients suspected to have acute appendicitis who were examined by sonography, 527 were males and 223 females. 468 patients had true acute appendicitis, and 220 patients were negative for this disease.

Thirty patients showed false positive diagnosis, while 32 patients proved to have false negative results. The overall sensitivity of ultrasound examination to diagnose acute appendicitis was $94 \%$, specificity $88 \%$, accuracy $92 \%$, positive predictive value $93 \%$ and negative predictive value was $88 \%$.

Conclusion: sonography must be used as first modality to assess suspected acute appendicitis. It is easy, non invasive, simple and rapid.

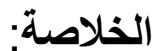

الهرف: لتقييم أهمية فحص الموجات فوق الصوتية في تشخيص حالات اشتباه التهاب الزائدة الدودية الحاد.

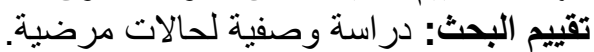

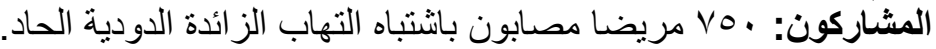

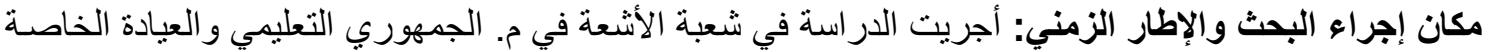

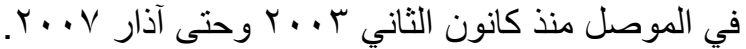

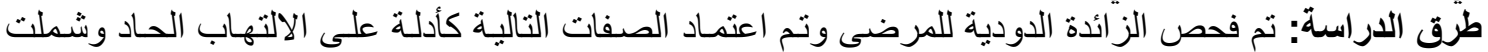

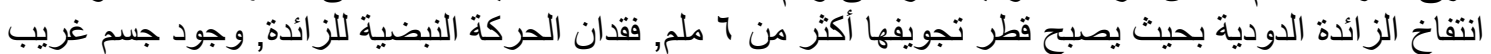

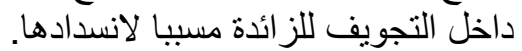
الانتخائج: داخ:

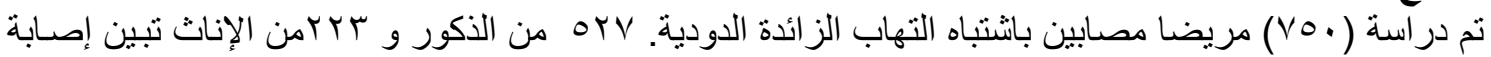

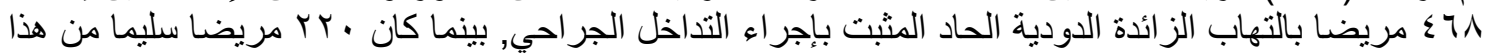
المرض.

تم اكتشاف ـ ـ مريضـا من الذين شخصهم فحص الموجات الفوق صسوتية بـان لديهم التهاب الزائدة الدوديـة بينمـا

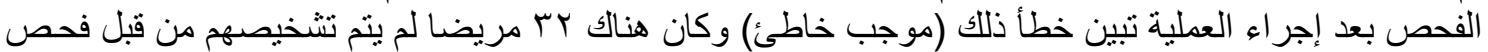

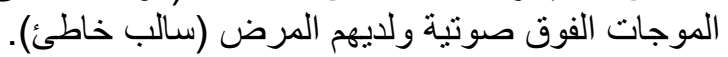

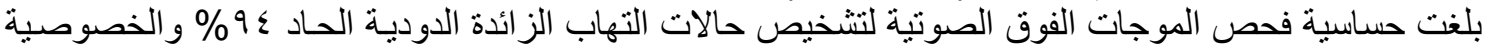

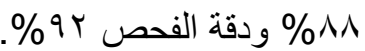
الاستتاج: فحص الموجات فوق الصوتية هو من الفحوصات السهلة الإجراء و السريعة, وغير تداخليه ولهذا يجب إجر اءه كفحص أولي في حالات الاشتباه بالتهاب الزوني الزون ائدة الدودية. 
A cute appendicitis is still the most common cause of emergency surgery of the abdomen ${ }^{(1)}$. Most of the investigators agree that $20-25 \%$ of appendices removed by surgery are normal $^{(2)}$. It remains one of the most difficult diagnoses to be made clinically ${ }^{(3)}$. Much of these difficulties stem from the variability in its clinical presentation because the classical presentation including periumbilical pain localizing to the right iliac fossa, vomiting, leucocytosis are generally seen in less than $50 \%$ of patients ${ }^{(3)}$. In acute appendicitis, the preoperative diagnosis is uncertain in $30 \%$ and despite the improvement in surgical techniques, the negative appendicectomy rate continues to be as high as $25 \%{ }^{(4)}$. Acute appendicitis can occur at any age but is more prevalent in young adults and it is the most common surgical problem reported in children and pregnant women ${ }^{(5,6)}$.

The complications of acute appendicitis include peritonitis, localized periappendicular abscess, thrombosis of portal vein drainage, liver abscess and septicemia $^{(7)}$. The rate of complications including death is directly related to the delay of diagnosis and delay in surgical treatment ${ }^{(8)}$. Mortality rate of simple appendicitis is $0.1 \%$ but it increases to 20 60 fold with perforation, and the rate of wound infection increases $35 \%$ with perforation $^{(8)}$.

Prospective studies have shown the overall accuracy of the clinical diagnosis to be not more than $70-78 \%$ in suspected appendicitis with correspondingly high rate of $20-25 \%$ unnecessary laparotomies ${ }^{(9)}$. Up to as many as $30 \%$ of patients with proven appendicitis are misdiagnosed and discharged by the physician before being correctly identified ${ }^{(10)}$. The negative laparotomies remain in the $20-25 \%$ range ${ }^{(11)}$, and this rate is higher in elderly women and children.

No laboratory test can establish the diagnosis of acute appendicitis with 100\% accuracy. The usefulness of white blood cells count for diagnosis of acute appendicitis is controversial. Plain radiograph, supine and upright films have long been used in the work-up of patients with suspected appendicitis. The findings include indistinctness of right psoas muscle margin, scoliosis of the spine, obliteration of peritoneal fat lines, soft tissue mass effect in the right lower quadrant, colonic cutoff sign (due to colonic spasm), localized small bowel ileus, calcified appendicoliths and free air in the peritoneal cavity ${ }^{(12)}$. Barium enema was used to diagnose acute appendicitis depending on visualizing the appendix $^{(13)}$.

Helical computerized tomography had a good role in the diagnosis of acute appendicitis but ionizing radiation and the use of intravenous contrast made it a relatively invasive test ${ }^{(14)}$.

The ultrasound finding associated with acute appendicitis had been investigated in the past ${ }^{(15)}$. It has several advantages over the other techniques mentioned. These are: 1-The structure being evaluated the appendix- is close to the surface of the abdomen.

2-The bowel can be displaced or compressed eliminating the disturbing gas artifacts.

3-The area of maximum tenderness indicated by the patient can be directly examined $^{(16-36)}$.

Ultrasound evaluation of patients with abdominal pain in suspected appendicitis includes visualization of non-compressible appendix more than $6-7 \mathrm{~mm}$ in diameter (from outer wall to outer wall diameter). One expert team has identified three criteria for diagnosis of appendicitis by ultrasound examination which include; tender noncompressible appendix, no peristalsis of the appendix and the over all diameter of the appendicular lumen is greater than $6 \mathrm{~mm}^{(17)}$.

The advantage of ultrasound examination to diagnose appendicitis is well known, the study is quick, readily available in most cases, non-invasive, has low complication risks and has been known to be accurate. High resolution ultrasound enables visualization of the inflamed appendix and can assess a variety of relevant disease. Bed-side ultrasound in evaluation of patients with suspected appendicitis is used nowadays as preliminary test ${ }^{(18-37-40)}$. The ultrasound diagnosis of acute appendicitis may be difficult if the appendix is not visualized, and this is especially common in obese patients. The ultrasound examination may be problematic if the patient suffers from acute pain which doesn't allow him to tolerate the pressure that must be applied with the probe on the right iliac fossa to permit visualization of the appendix ${ }^{(19)}$. The overall accuracy of ultrasound examination in the diagnosis of acute appendicitis in most 
of the studies was about $85 \%$, so that it appears to be most useful in the early stage of the disease and it can be easily repeated to reach final diagnosis ${ }^{(20)}$.

The study aims to assess the validity of ultrasound examination in the diagnosis of acute appendicitis.

\section{Patients and methods:}

A total of (750) patients referred to the radiology section in AL-Jamhory Hospital from January 2003 to March 2007 with clinical suspicion of acute appendicitis were examined by ultrasound using "Aloka SSD 500 equipment". Some of these patients were examined in my private clinic on afternoon using Shimadzu C-32 equipment. A linear array transducer usually $5 \mathrm{MHZ}$ is used in examination.

The patient is examined in supine position and is initially asked to point the area of maximum tenderness. Scanning of the patient should be initiated in the region of maximal pain indicated by the patient to expedite the sonographic evaluation and this is called self-localizing technique ${ }^{(21)}$. If no abnormality is found, then transverse and longitudinal images are obtained of the abdomen, including the right lower quadrant and the right lateral abdomen extending from subhepatic location to the pelvis.

In all areas examined, the anterior abdominal wall is compressed slowly but firmly with the ultrasound transducer to displace normal bowel loops in an effort to locate the inflamed appendix. This procedure is called graded compression ultrasonogrpahy. If an apparently normal appendix is identified, a careful survey of the entire length of the appendix should be performed to avoid false negative examination when the inflammation is confined to the tip of the appendix ${ }^{(22,38)}$. Sometimes I use posterior manual compression of the abdominal wall to help to visualize the appendix.

In the transverse plane of the appendix, alternating echogenic and hypoechoic concentric layers should be sought, corresponding to the visualization of various layers of the bowel wall. An inner-most hyperechoic layer corresponds to the interface between the mucosa and intraluminal contents. Hypoechoic layer corresponds to muscularis mucosae. A middle hyperechoic layer corresponds to the submucosa. An outer hypoechoic, layer corresponds to the muscularis propria. And peripheral hyperechoic layer corresponds to the serosa ${ }^{(23)}$. The fluid within the appendiceal lumen appears as an inner hypoechoic central sonolucency. A positive examination consists of visualization of the appendix. Fig. (1)

The diagnostic findings of examined patients were documented and such patients were followed to assess the type of treatment. Patients who underwent surgical operation were recorded and the postoperative results were compared with the ultrasound findings.

The sensitivity, specificity and accuracy with other statistical values are concluded using $2 \times 2$ table.

\section{Results:}

The sample included 750 patients. Their ages ranged from (6) years to (70) years forming (7) age groups according to decades of age including their liver spans, which are measured Fig.(2). Of these patients there are $527(70 \%)$ male and $223(30 \%)$ females with a sex ratio of $2.3: 1$.

Distribution of patients according to final diagnosis is shown on Fig. (3).

Thus $468(67 \%)$ patients who are diagnosed as acute appendicitis proved by surgery to have this diagnosis. The ultrasonographic criteria for acute appendicitis are shown in Table (1).

Other findings in association with perforated appendix include thickening of the adjacent bowel wall, atonic bowel loops, interloop fluid pockets, periappendicular fluid and abscess are encountered in 20 patients with acute appendicitis and perforation. Fig. (4).

The 30 patients in whom ultrasound showed positive signs of acute appendicitis and after surgery proved to be normal appendices are considered false positive diagnosis, and the surgical result shows the real cause of these cases ranging between ruptured ovarian cyst, cecal diverticulae, psoas muscle hematoma, inspissated stool mimicking an appendicolith and mesenteric adenitis.

In the 252 (33\%) patients where the ultrasound finding showed negative signs of acute appendicitis, they were followed after sonographic examination and 220 patients of them showed no any aggravation of their clinical symptoms and their final diagnosis on discharge was not acute appendicitis. Hence, they were considered true negative cases on statistical bases. In these cases 
normal appendix is visualized in 198(90\%) cases only and the rest were not visualized, and in all these patients no sonographic signs of acute appendicitis were encountered. So these 220 patients are considered true negative cases on statistical bases.

In the remaining 32 patients where initial sonographic results showed negative sign for acute appendicitis actually were exposed to surgical laparatomies because they continued to have clinical symptoms that were suggestive of acute appendicitis and this diagnosis was actually proved later by surgery and histopathology of the appendix. Therefore these 32 patients were considered false negative cases on statistical analysis.

The final statistical analysis are shown as follows: The overall sensitivity of ultrasound examination in diagnosis of acute appendicitis in this study is $94 \%$; specificity $88 \%$. The positive predictive value $\mathrm{PPV}=93 \%$ while negative predictive value $\mathrm{NPV}=88 \%$ and the overall accuracy is $92 \%$.

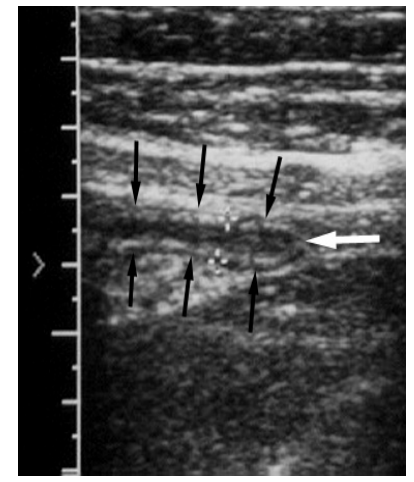

Fig. (1): Sonographic appearance of normal appendix.

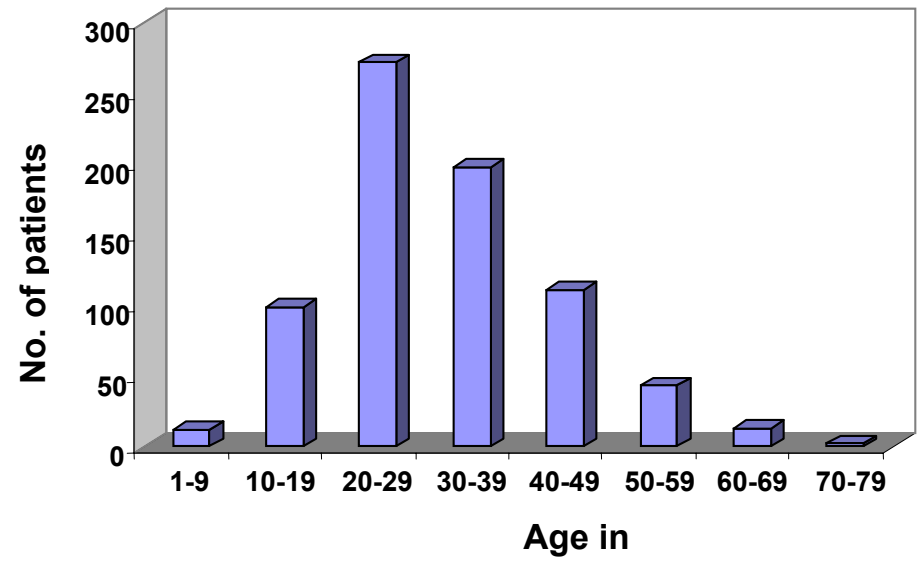

Fig. (2): Histogram demonstrates the age distribution of patients.

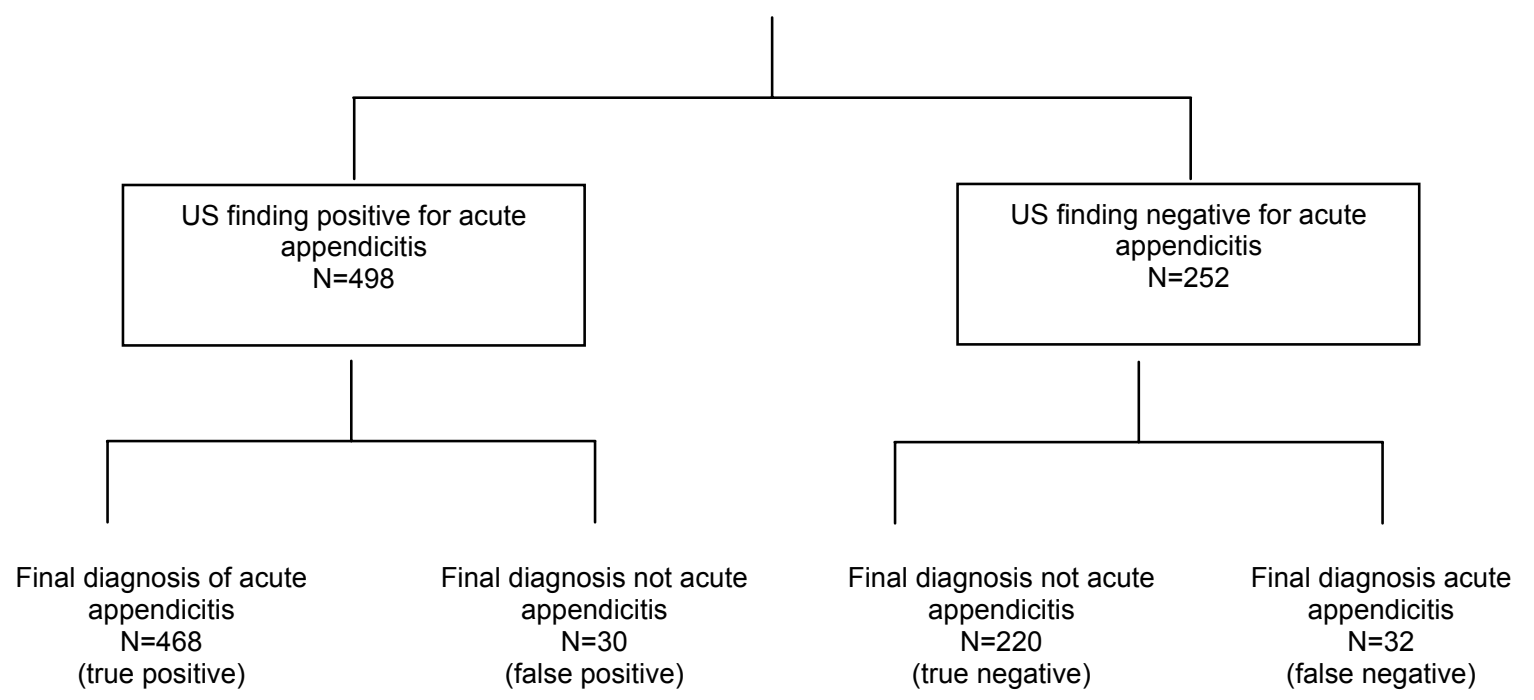

Fig. (3): Distribution of the patients according to the final diagnosis. 
Table (1): Sonographic findings of acute appendicitis in 468 patients.

\begin{tabular}{|c|c|}
\hline Sonographic sign & $\%$ \\
\hline Diameter of the appendicular lumen more than (6) $\mathrm{mm}$. & $100 \%$ \\
\hline Blind ending tubular structure filled with fluid, aperistaltic. & $90 \%$ \\
\hline Non-compressible appendix & $88 \%$ \\
\hline Echogenic submucosa & $65 \%$ \\
\hline Presence of appendicolith & $40 \%$ \\
\hline Free intra peritoneal fluid & $15 \%$ \\
\hline
\end{tabular}

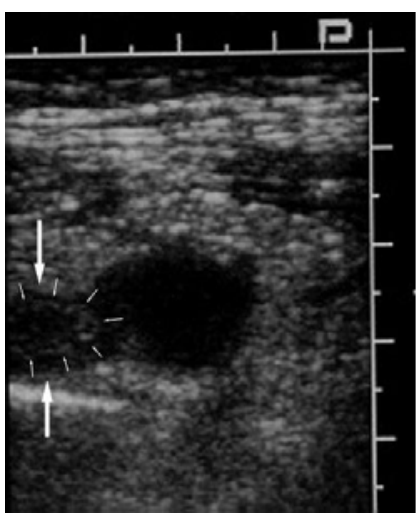

Fig. (4): Sonographic appearance of perforated appendix.
Table (2): validity of sonographic assessment in acute appendicitis.

\begin{tabular}{|l|c|c|c|c|c|}
\hline \multicolumn{1}{|c|}{$\%$} & $\begin{array}{c}\text { D.S } \\
\text { Wade } \\
\text { et al. } \\
(28)\end{array}$ & $\begin{array}{c}\text { Toe } \\
\text { et } \\
\text { al.(29) }\end{array}$ & $\begin{array}{c}\text { Sodak } \\
\text { et al. } \\
(30)\end{array}$ & $\begin{array}{c}\text { Schwerk } \\
\text { et al. } \\
(31)\end{array}$ & $\begin{array}{c}\text { Present } \\
\text { study }\end{array}$ \\
\hline \hline Sensitivity & 85.5 & 92 & 86.7 & $75-92$ & 94 \\
\hline Specificity & 84.4 & 96.9 & 90 & $92-100$ & 88 \\
\hline $\begin{array}{l}\text { Positive } \\
\text { predictive } \\
\text { value (PPV) }\end{array}$ & 88.3 & 89.7 & 94.5 & 89 & 93 \\
\hline $\begin{array}{l}\text { Negative } \\
\text { predictive } \\
\text { value (NPV) }\end{array}$ & 80.1 & 97.9 & 79.9 & 96 & 88 \\
\hline Accuracy & 85 & 96 & 88 & 87 & 92 \\
\hline
\end{tabular}

\section{Discussion:}

This study utilizes the role of ultrasonography for the assessment of cases with suspected acute appendicitis and its influence upon patient management and outcome. We evaluate the usefulness of graded compression sonography with the adjuvant use of posterior manual compression technique to detect the appendix ${ }^{(38,39,41)}$.

Diagnostic ultrasound imaging of the appendix has improved steadily over the past decade and has been used traditionally as a primary modality in children with suspected acute appendicitis (24). It is very safe, fast, needs no ionizing radiation, non-invasive and considered most beneficial for paediatric age and pregnant patients ${ }^{(15)}$.

Regarding this study, the peak age of patients suffering from acute appendicitis was between 20-30 years. This can be explained on the amount of lymphoid tissue present inside the appendix which is very little at birth and increases with age to reach the peak at 20-35 years and then starts to regress. Obstruction of the lumen of the appendix is thought to be due to lymphoid tissue hyperplasia beside the presence of fecolith ${ }^{(25)}$.

Most of the studies which were done by expert teams had identified three main criteria for the diagnosis of acute appendicitis which include ${ }^{(17,33)}$ :

1- The overall diameter of the appendicular lumen is more than (6) $\mathrm{mm}$.

2- tender non-compressible appendix.

3- Aperistaltic appendix.

The dilated lumen of the appendix was very important index for diagnosis of acute 
appendicitis in our study and it was shown in $100 \%$ of our patients.

This is similar to Quillin et al. and Hayden et al. (1992); both showed the significance of this sign in their patients as $100 \%$, and $98 \%$ respectively. ${ }^{(19,32)}$

The normal appendix was not always depicted in our study. It was seen only in 198 patients $(90 \%)$ of the 252 true negative cases and was not visualized in the remaining 54 patients. Therefore, nonvisualization of the appendix with the absence of any other inflammatory sign was interpreted as negative of appendicitis in accordance with other studies by Balthazar and Kamel et al. $(26,27)$

In this study there were 32 patients who had acute appendicitis proved after appendicectomies, but the preoperative sonographic diagnosis failed to label that (false negative). The causes of failure include retrocecal inflamed appendix when the dilated atonic caecum prevents the visualization of the appendix, moderate bowel ileus, small bowel obstruction, obesity and severe right iliac fossa tenderness which prevents proper graded compression examination $^{(18,34)}$.

On the other hand we came across 30 patients who were diagnosed to have acute appendicitis by ultrasound and postoperatively the appendices proved to be normal (false positive). This was due to other causes like hydrosalpinx, tubovarian abscesses, Crohn's disease, psoas muscle haematoma, inspissated stool mimicking an appendicolith. These diseases give features that simulate a dilated inflamed appendix. Most of the studies mentioned that the factors which decrease the reliability of sonographic evaluation of appendicitis include obesity, overlying bowels gas, nature of sonographic modality beside the ultrasound examination is being operator dependent and needs good experience in this field. ${ }^{(28,35)}$

The validity of sonographic assessment in acute appendicitis involved in our study as compared to other studies is shown in table(2).

Besides the known criteria of acute appendicitis mentioned in table (1), we conclude an associated sign in almost all the cases of acute appendicitis and this is an increased echogenicity of the portal veins radicle through the liver; in other words, there are periportal veins increased echogenecity. This is mostly due to thrombophlebitis of these vein radicles due to portal blood drainage from the inflamed appendix. It was a good index of acute appendicitis.

\section{Conclusion:}

1- Ultrasonography is an accurate modality in the diagnosis of acute appendicitis and it is most useful in patients with acute equivocal clinical findings, so it should be the first modality used in this aspect.

2- The efficacy of sonographic assessment for acute appendicitis was superior to that of surgeon's initial clinical impression $(P<0.001)$ which is highly significant.

3- The early and accurate diagnosis of appendicitis can decrease the morbidity and hospital cost by reducing the delay in diagnosis of appendicitis and its associated complications, as well as by avoiding inpatient observation prior to surgery in patient who presents with typical symptoms. Furthermore ultrasound may provide alternative diagnosis which could be treated on out patient basis.

4- Being easy, fast, non-invasive, ultrasonography has advantages over other imaging modalities in diagnosis of acute appendicitis, and besides sonography can be available in every casualty department ready for this job.

\section{References:}

1. Puylaert: Acute appendicitis. Ultrasound evaluation using graded compression. Radiology 1996; 158: 355.

2. Abu-Yousif MM, Bleicher JJ, Maher JW et al. High resolution sonography of acute appendicitis AJR 1997; 149: 53.

3. Lewis FR, Holcroft JW, Boey J, Dunphy JE. Appendicitis: A critical review of diagnosis and treatment in 1000 cases. Archives of surgery 1975; 110:1, 677684.

4. Parulekar SG. Ultrasonographic finding in disease of the appendix. J ultrasound Med. 1993; 2: 59.

5. Robbins SL, Cotran RS: The gastrointestinal tract in pathologic basis of disease Philadelphia WB Saunders. (1997); 918. 
6. Cook country hospital. Archieve surgery 1979; 114:717-719.

7. Yeh HC, Rabinowitz JG, ultasonography of gastro intestinal tract Semin ultrasound CT MR 1982; 3: 331.

8. A reappraisal of appendicitis in elderly Am. J Surgery 1990; 160:291-293.

9. Medizinischen klinik des stadtischenkiel MMW fortscher Med 2000 Jul 6; 42(2627): 29-32.

10. Rogers J. Abdominal pain: Foresign Dallas American college of emergency 1986 issue 3.

11. Slakin MS. Appendicitis avoiding failure to diagnose 1996; 7: 113-124.

12. Franken AJR. Gastrointestinal imaging in paediatric $2^{\text {nd }}$ Ed. New York, Harper and Row 1982; 319-324.

13. Preston CA, Karch SB. The influence of gender and use of Ba-enema on morbidity in acute appendicitis Am. J. Emerg. Med. 1989; 7: 253-255.

14. Rao PM, Rhea JT, Novelline RA, McCabe CJ, Lawrason JN, Berger DL. Helical CT technique for the diagnosis of appendicitis prospective evaluation of a focused appendix CT examination. Radiology 1997; 202:139-144.

15. Monzer M. Abu-Yousef MD. Ultrasonography of the right lower quadrent ultrasound. $2001 ; 17$ : 4, 211225.

16. Jeffery RB JR, Laing FC, Lewis FR: Acute appendicitis high-resolution real time ultrasound finding. Radiology 1997; 163:11.

17. Jeffery RB JR, Laing FC, Townsend RR. Acute appendicitis. Sonographic criteria based on 250 cases. Radiology 1998; 167: 357-359.

18. Pieper R, Kager L, The incidence of acute appendicitis and appendicectomy. An epidemiological study of 971 cases. Acta Chir-Scand 1982; 148: 45-49.

19. Hayden JRCK, Kuchelmeister J, Lipscomb TS. Sonography of acute appendicitis J. Ultrasound 1992; 11: 209216.

20. MMW Fortscher. Ultrasound first in acute appendix? Unnecessary laparotomies can often be avoided Med. 2000; 142: 2932.

21. Chesbrough RM, Burkhard TK, Balsara ZN, Goff WB, Davis DJ. Self localization in US of appendicitis. An addition to graded compression. Radiology 1993; 187: 349-351.
22. Nghiem HV, Jeffery RB Jr. Acute appendicitis confined to the appendiceal tip: evaluation with graded compression sonogrpahy.

Ultrasound Med 1992; 11: 205-207.

23. Spear R, Kimmey MB, Wang KY, Sillery JK, Benjamin DR, Sawin RS. Appendicitis US scan. Histological correlation. Radiology 1992; 183, 831834.

24. Lund DP, Murphy EU. Management of acute appendicitis in children. J. Paediatric Surg 1994; 29:1130-1134.

25. Arnobjornsson E, Bengmank S. obstruction of the appendix lumen in relation to pathogenesis of acute appendicitis. Acta Chir Sand 1998; 149: 789-791.

26. Balthazar EJ, Birubaum BA, Yee J. Acute appendicitis. C.T. and US Radiology 1994; 190: 31-35.

27. Kamel IR, Goldberg SN, Koegan MT. Right lower quadrant pain and suspected appendicitis. Radiology 2000; 217:153.

28. D.S Wade, S.E. Marrow, Z.N Balsara, TK Burkhard and W.B. Goff. Accuracy of ultrasound in the diagnosis of acute appendicitis compared to surgical clinical impression. Arch. Surg. 1993; 128: 1-3.

29. Toe El, Tan KP, Law SL, Ong CL, Wong CS. Ultrasonography and computerized tomography in clinical algorithm for evaluation of acute appendicitis. Singapour Med. 2000; 4:387-392.

30. Sodak, Nemoto K, Yoshizawa S, Hibiki T, Shizuya K, Konishi F. Detection of pin point tenderness on the appendix under ultrasonography is useful to confirm acute appendicitis. Arch. Surg. 2001; 1136-1140.

31. Schwerk WB. Ultrasound first in acute appendicitis? Unnecessary laparotomies can often be avoided. MMW Fortsch Med. 2000; 142:26-27.

32. Quillin SP. Siegel MJ. Appendicitis efficacy in color Dopplar sonography. Radiology 1994; 191: 557-560.

33. Thomas M.D., Peter MD, Florian MD, The outer diameter of the vermiform appendix as a sign of acute appendicitis. Radiology 2001; 218: 757762.

34. Garcia-Aguayo, Gil P. Sonography in acute appendicitis: diagnostic utility and 
influence upon management and outcome. Eur Radiol 2001; 10(12): 1886-93.

35. Dilley A, Wesson D, Munden M, Hick J, The impact of ultrasound examination in the management of children with suspected appendicitis: a 3-year analysis. J Peadiatric Surgery 2001; 36(2): 303-306.

36. K. Soda, K. Nemoto, S. Yoshizawa, T. Hibiki, K. Shizuya and F. Konishi. Detection of pinpoint tenderness on the appendix under ultrasonography is useful to confirm acute appendicitis. AJR 2001; 136(10): 1136-1140.

37. Fischer T, Filimonow S, Petersein J, Beyersdorff D, Muhler M, Hamm B. Ultrasound at the bedside: Dose a portable device save time? Ultraschall Med 2002; 23(5): 311-4.
38. Lee JH, Jeong YK, Hwang JC, Ham Sy, Yang SO. Graded compression sonography with adjuvant use of a posterior manual compression technique in the sonographic diagnosis of acute appendicitis. AJR 2002; 178(4): 863-8.

39. Gritzmann N, Hollerweger A, Macheiner $P$, Rettenbacher T. Transabdominal sonography of gastrointestinal tract. Eur Radiol 2002; 12(7): 1748-61.

40. J. Christian Fox, Matthew Solley, Alexander Zlidenny and Craig Anderson. Bedside ultrasound for appendicitis. Acad Emerg Med 2005; (12): 5, 76.

41. Audrey Harris, M. Ed, R.T. and Norman E, Bolus M.P.H. Appendicitis imaging. Radiologic Technology 2005; 77:111117. 